\title{
DNA single strand breakage, DNA adducts, and sister chromatid exchange in lymphocytes and phenanthrene and pyrene metabolites in urine of coke oven workers
}

Walter Popp, Carola Vahrenholz, Christiane Schell, Gernot Grimmer, Gerhard Dettbarn, Rudolf Kraus, Andreas Brauksiepe, Barbara Schmeling, Thomas Gutzeit, Juliane von Bülow, Klaus Norpoth

\begin{abstract}
Objectives-To investigate the specificity of biological monitoring variables (excretion of phenanthrene and pyrene metabolites in urine) and the usefulness of some biomarkers of effect (alkaline filter elution, ${ }^{32} \mathbf{P}$ postlabelling assay, measurement of sister chromatid exchange) in workers exposed to polycyclic aromatic hydrocarbons (PAHs).

Methods-29 coke oven workers and a standardised control group were investigated for frequencies of DNA single strand breakage, DNA protein cross links (alkaline filter elution assay), sister chromatid exchange, and DNA adducts ( ${ }^{32} P$ postlabelling assay) in lymphocytes. Phenanthrene and pyrene metabolites were measured in 24 hour urine samples. 19 different PAHs (including benzo(a)pyrene, pyrene, and phenanthrene) were measured at the workplace by personal air monitoring. The GSTT1 activity in erythrocytes and lymphocyte subpopulations in blood was also measured.
\end{abstract}

Results-Concentrations of phenanthrene, pyrene, and benzo(a)pyrene in air correlated well with the concentration of total PAHs in air; they could be used for comparisons of different workplaces if the emission compositions were known. The measurement of phenanthrene metabolites in urine proved to be a better biological monitoring variable than the measurement of 1-hydroxypyrene. Significantly more DNA strand breaks in lymphocytes of coke oven workers were found (alkaline filter elution assay); the DNA adduct rate was not significantly increased in workers, but correlated with exposure to PAHs in a semiquantitative manner. The number of sister chromatid exchanges was lower in coke oven workers but this was not significant; thus counting sister chromatid exchanges was not a good variable for biomonitoring of coke oven workers. Also, indications for immunotoxic influences (changes in lymphocyte subpopulations) were found.

Conclusions-The measurement of phenanthrene metabolites in urine seems to be a better biological monitoring variable for exposure to PAHs than measurement of hydroxypyrene. The alkaline filter elution assay proved to be the most sensitive biomarker for genotoxic dam- age, whereas the postlabelling assay was the only one with some specificity for DNA alterations caused by known compounds.

(Occup Environ Med 1997;54:176-183)

Keywords: coke oven workers; DNA adducts; PAH metabolites

It has been proved by epidemiology that there is an increased risk of cancer for coke oven workers. Various carcinogenic substances can be measured in the workplace atmosphere of coke ovens-for example, benzene, arylamines, and polycyclic aromatic hydrocarbons (PAHs). The increased risk of lung cancer of coke oven workers may be mainly caused by PAHs, important products of pyrolysis at the workplace. ${ }^{1}$ There is an urgent need to find sensitive and specific variables for biological monitoring to measure the internal exposure of coke oven workers. These variables may also be used for other workplaces; PAHs are relevant hazards for other groups of workers with exposure to products of pyrolysis-for example, aluminium potroom workers, chimney sweeps, and workers producing graphite electrodes. Also, PAHs are important carcinogenic substances in cigarette smoke. Coke ovens as workplaces have a high exposure to carcinogens, and therefore are suitable for investigating new methods of biological monitoring and biomarkers of effect.

This investigation has been carried out on an older coke plant in Germany to study whether different variables of biological monitoring (excretion of phenanthrene and pyrene metabolites in urine) and biomarkers (measurement of the frequency of DNA single strand breakage (by alkaline filter elution), sister chromatid exchanges, and DNA adducts (by ${ }^{32} \mathrm{P}$ postlabelling)) can be used to assess and classify occupational exposure to the products of pyrolysis and measure genotoxic damage. Also, we measured different lymphocyte subpopulations to measure influences on the cellular immune system.

\section{Materials and methods}

SUBJECTS

Twenty nine male coke oven workers in Germany were investigated (16 smokers, 13 non-smokers; 26-56 years old; who had 
worked on coke ovens for six to 24 years). We also investigated the same biological effect markers (alkaline filter elution assay, measurement of sister chromatid exchanges, DNA adducts, and lymphocyte subpopulations) in a control group standardised by number, smoking habits, sex, and age (maximum variation of five years within the matched pairs). The controls were healthy and without known exposure to occupational and environmental carcinogens.

Each person answered a questionaire on personal data-namely, smoking and alcohol habits, use of drugs, diseases, holidays during the past weeks, and hobbies - and data on the workplace and working history.

\section{BLOOD AND URINE SAMPLES}

Urine was collected from the beginning of the shift in which air monitoring was carried out to the beginning of the shift the next morning.

Venous blood was taken (at the beginning of the morning shift on the day after air monitoring) with $25 \mathrm{ml} \mathrm{LH}$ monovettes (Sarstedt, $15 \mathrm{IU}$ lithium heparin $/ \mathrm{ml}$ blood) and $9 \mathrm{ml}$ monovettes $\mathrm{KE}$ (Sarstedt, $1.6 \mathrm{mg}$ EDTA $/ \mathrm{ml}$ blood). The blood samples were cooled to about $5^{\circ} \mathrm{C}$ by freeze packs and transported to the laboratory within five hours, with as little vibration as possible. The blood was used immediately. The urine was frozen and stored at $-60^{\circ} \mathrm{C}$ until analysis.

\section{ALKALINE FILTER ELUTION}

Heparinised blood was diluted at a ratio of $1: 3$ (v/v) with Eagle's minimum essential medium in Hank's balanced salt solution and the lymphocytes were isolated on Percoll gradients (Biochrom KG, Seromed). If necessary, any erythrocytes remaining were lysed by incubation with $150 \mathrm{mM} \mathrm{NH}_{4} \mathrm{Cl}, 10 \mathrm{mM} \mathrm{KHCO}_{3}, 1$ $\mathrm{mM} \mathrm{Na} \mathrm{N}_{2}$-EDTA for three minutes at $0^{\circ} \mathrm{C}$, and the lymphocytes were collected by centrifugation and then resuspended in phosphate buffered saline.

V79 cells (hamster fibroblasts) were cultured in Dulbecco's minimum essential medium with $10 \%(\mathrm{v} / \mathrm{v})$ horse serum, $10 \%$ (v/v) HEPES, and $7 \cdot 5 \%$ sodium hydrogen carbonate and L-glutamine. Confluent growing V79 cells were harvested by trypsination immediately before elution.

Alkaline filter elution was carried out with a slight modification of the method described by Doerjer et al. ${ }^{2}$

A suspension containing a million cells was poured on to each filter (polycarbonate filter; pore diameter: $2.0 \mu \mathrm{M}$; Nucleopore, Pleasanton, CA, USA). Cells were lysed with $3 \mathrm{ml} 2 \mathrm{M} \mathrm{NaCl}, 10 \mathrm{mM} \mathrm{Na} \mathrm{NaDTA}_{2}$-E.5\% Triton $\mathrm{X} 100, \mathrm{pH} 10$ with or without 0.5 $\mathrm{mg} / \mathrm{ml}$ proteinase $\mathrm{K}$ for 60 minutes and then washed with $10 \mathrm{mM} \mathrm{Na}$-EDTA, pH 10 . The samples were eluted with a solution of $2 \mathrm{M}$ $\mathrm{NaCl}, 0.02 \mathrm{M} \mathrm{Na}_{2}$-EDTA, $0.5 \mathrm{M} \mathrm{H}_{3} \mathrm{BO}_{3}$, and $0.65 \mathrm{M} \mathrm{NaOH}, \mathrm{pH} 12 \cdot 6$. The eluate collected in the first 40 minutes was discarded. The fractions were collected for 10 hours. The eluates, filter extracts, and rinsing fractions of the filter holders and tubes were neutralised with 3
$M \mathrm{NaH}_{2} \mathrm{PO}_{4}, 3 \mathrm{M} \mathrm{H}_{3} \mathrm{PO}_{4}$. After reaction with the fluorochrome Hoechst 33258 (final concentration $0.5 \mu \mathrm{M}$ ) the DNA concentrations were measured at $360 \mathrm{~nm}$ excitation and 450 $\mathrm{nm}$ emission. Measurements were carried out in triplicate for each subject.

These results were used to calculate the DNA retention (D) of the filter as a percentage of the total amount of DNA; the elution rate $(k)$ was calculated from $k=2 \log \mathrm{D}$. The relative elution rates $\left(k_{\text {rel }}\right)$ were calculated from the elution rates obtained for the V79 $\left(k_{\mathrm{v} 79}\right)$ cells, which were measured simultaneously $\left(\mathrm{k}_{\mathrm{rel}}=\mathrm{k} / \mathrm{k}_{\mathrm{v} 79}\right) .^{2-6}$

\section{MEASUREMENT OF THE FREQUENCY OF SISTER} CHROMATID EXCHANGE

Heparinised blood $(400 \mu \mathrm{l})$ was incubated for 72 hours at $37^{\circ} \mathrm{C}$ in $5 \mathrm{ml}$ Roswell Park Memorial Institute (RPMI) 1640 medium (Boehringer) with glutamine, penicillin (115 U/ml), streptomycin $\quad(115 \mu \mathrm{g} / \mathrm{ml})$, amphotericin B $(0 \cdot 29 \mu \mathrm{g} / \mathrm{ml}), 20 \%$ fetal calf serum (Flow), phytohaemagglutinin $\mathbf{M}$ (Gibco), and $10^{-5} \mathrm{M}$ BrdU. Treatment of the cultures with Colcemid and hypotonic $\mathrm{KCl}$ solution, fixation, preparation of the chromosomes, and fluorescence plus Giemsa staining of the preparation were carried out according to the method of Perry and Wolff. ${ }^{7}$ The frequency of sister chromatid exchange was measured by examining 25 complete second metaphases per subject; the value of sister chromatid exchanges for each subject was taken as the mean of the frequencies of sister chromatid exchange counted per metaphase.

\section{MEASUREMENT OF DNA ADDUCTS}

Mononuclear white blood cells were collected after separation from whole blood through a Percoll gradient (Biochrom Seromed, Germany $)^{6}$ and stored immediately at $-80^{\circ} \mathrm{C}$. The DNA was isolated from the cells by treatment with RNase and proteinase $\mathrm{K}$, followed by a solvent extraction procedure. ${ }^{8}$ The concentration of DNA was estimated spectrophotometrically and samples were stored at $-20^{\circ} \mathrm{C}$ until analysis.

The DNA adducts were analysed by the nuclease P1 enhancement procedure, essentially as described elsewhere. ${ }^{910}$ Briefly, $10 \mu \mathrm{g}$ of DNA was digested to 3'-mononucleotides with $2 \mu \mathrm{g}$ each of micrococcal nuclease and spleen phosphodiesterase at $37^{\circ} \mathrm{C}$ overnight. The dephosphorylation of normal nucleotides was carried out at $37^{\circ} \mathrm{C}$ for one hour by adding $4.8 \mu \mathrm{g}$ of nuclease P1. Samples were labelled with $100 \mu \mathrm{Ci}$ of commercially prepared $\left(\gamma^{32} \mathrm{P}\right)$ ATP $(7000 \mathrm{Ci} / \mathrm{mmol}$ ICN) with 3.5 units of $\mathrm{T} 4$ polynucleotide kinase (Boehringer Mannheim, Germany). Purification and resolution of ${ }^{32} \mathrm{P}$ labelled adducts was carried out on PEI cellulose TLC sheets (Macherey and Nagel, Germany) with the following solvent systems: $\mathrm{D} 1,1 \mathrm{M}$ sodium phosphate, $\mathrm{pH} 6$; D3, 3.5 M lithium formate, 8.5 M urea, $\mathrm{pH} 3.5$; D4, $0.8 \mathrm{M}$ lithium chloride, $8.5 \mathrm{M}$ urea, $0.5 \mathrm{M}$ Tris- $\mathrm{HCl}, \mathrm{pH} 8 ; \mathrm{D} 5$, $1.7 \mathrm{M}$ sodium phosphate, $\mathrm{pH} 6$. The chromatograms were viewed after autoradiography 
Table 1 Concentrations of PAHs $\left(\mu \mathrm{g} / \mathrm{m}^{3}\right)$ for 27 coke oven workers

\begin{tabular}{|c|c|c|}
\hline$P A H$ & Mean $(S D)$ & Range \\
\hline $\begin{array}{l}\text { Phenanthrene } \\
\text { Anthracene } \\
\text { Fluoroanthene } \\
\text { Pyrene } \\
\text { Benzo(b)naphtho(2,1-d)thiophene } \\
\text { Benzo(ghi)fluoranthene } \\
\text { Benzo(c)PHE } \\
\text { Cyclopenteno(cd)pyrene } \\
\text { Benzo(a)anthracene } \\
\text { Chrysene + triphenylene } \\
\text { Benzofluoranthene(b + j+k) } \\
\text { Benzo(e)pyrene } \\
\text { Benzo(a)pyrene } \\
\text { Perylene } \\
\text { Indeno(1,2,3-cd)pyrene } \\
\text { Dibenz(a,h)anthracene } \\
\text { Benzo(ghi)perylene } \\
\text { Anthanthrene } \\
\text { Coronene }\end{array}$ & $\begin{array}{l}16.11(9.00) \\
3.33(2.63) \\
6.33(4.32) \\
3.82(2.54) \\
1.01(0.59) \\
0.36(0.27) \\
0.44(0.35) \\
0.49(0.35) \\
3.11(1.67) \\
3.33(1.67) \\
3.99(1.87) \\
1.63(0.76) \\
1.74(0.82) \\
0.41(0.19) \\
1.04(0.45) \\
0.37(0.18) \\
1.16(0.54) \\
0.38(0.30) \\
0.16(0.12)\end{array}$ & $\begin{array}{l}4 \cdot 67-41 \cdot 91 \\
0 \cdot 33-14 \cdot 08 \\
1 \cdot 23-18 \cdot 94 \\
0 \cdot 88-11 \cdot 31 \\
0 \cdot 24-2 \cdot 93 \\
0 \cdot 11-1 \cdot 26 \\
0 \cdot 10-1 \cdot 65 \\
0 \cdot 08-1 \cdot 35 \\
0 \cdot 92-8 \cdot 14 \\
0 \cdot 97-7 \cdot 31 \\
1 \cdot 03-7 \cdot 74 \\
0 \cdot 50-3 \cdot 20 \\
0 \cdot 47-3 \cdot 55 \\
0 \cdot 11-0 \cdot 87 \\
0 \cdot 34-1 \cdot 93 \\
0 \cdot 10-0 \cdot 88 \\
0 \cdot 41-2 \cdot 38 \\
0 \cdot 09-1 \cdot 06 \\
0 \cdot 01-0.43\end{array}$ \\
\hline Total PAHs & $49 \cdot 21(27 \cdot 42)$ & $13 \cdot 98-127 \cdot 37$ \\
\hline
\end{tabular}

at $-80^{\circ} \mathrm{C}$ with intensifying screens for at least 72 hours. Adduct levels were measured by Cerenkov counting and calculated taking into account the quantity of DNA labelled and the specific activity of the ATP used. The results are given as the total number of adducts per $10^{9}$ normal nucleotides. A positive control of benzo(a) pyrene-diol-epoxide (BPDE) reacted calf thymus DNA and negative controls of non-adducted calf thymus DNA were routinely assayed with experimental samples. Each sample was analysed at least in triplicate in independent assays.

\section{RELATIVE DISTRIBUTION OF LYMPHOCYTE SUBPOPULATIONS BY FLOW CYTOMETRY} To investigate lymphocyte phenotypic markers $100 \mu \mathrm{l}$ whole blood of each coke oven worker were incubated with monoclonal antibodies against CD2 (T cells), CD4 (helper/inducer T cells), CD8 (cytotoxic/suppressor $\mathrm{T}$ cells), CD19 (B cells), CD56 (NK cells) and CD71 (proliferating cells) (Coulter Electronics, Germany) for 10 minutes at room temperature. After that, blood was lysed, stabilised, and fixed (Q-Prep, Coulter). Measurements were made with a flow cytometer Profile II (Coulter Electronics, Germany).

\section{GSTT1}

The phenotype of GSTT1 was measured in lysed erythrocytes. The erythrocytes were collected after the Percoll gradient separation, washed and lysed with the same volume of distilled water. The enzyme assay used has been described by Peter et al. ${ }^{11}$

Table 2 Concentrations (mean (SD) in $\mu \mathrm{g} / \mathrm{m}^{3}$ ) of pyrene, benzo(a)pyrene, and total $P A H$ for 27 coke oven workers related to smoking and job

\begin{tabular}{llll}
\hline Variable $(n)$ & Pyrene & Benzo(a)pyrene & Total PAHs \\
\hline All (27) & $3 \cdot 82(2 \cdot 54)$ & $1 \cdot 74(0 \cdot 82)$ & $49 \cdot 21(27 \cdot 42)$ \\
Smokers (14) & $3 \cdot 53(2 \cdot 51)$ & $1 \cdot 62(0 \cdot 89)$ & $46 \cdot 34(30 \cdot 16)$ \\
Non-smokers (13) & $4 \cdot 13(2 \cdot 64)$ & $1 \cdot 88(0 \cdot 75)$ & $52 \cdot 30(24 \cdot 97)$ \\
Top side (11) & $5 \cdot 09(2 \cdot 23)$ & $2 \cdot 25(0 \cdot 50)$ & $65 \cdot 13(17.94)$ \\
Coke side (16) & $2 \cdot 95(2 \cdot 42)$ & $1 \cdot 39(0 \cdot 83)$ & $38 \cdot 26(27 \cdot 84)$ \\
P value (Wilcoxon test) & $0 \cdot 0042$ & $0 \cdot 0033$ & $0 \cdot 0013$ \\
P value (Jonckheere-Terpstra test) & $0 \cdot 0019$ & $0 \cdot 0015$ & $0 \cdot 00067$ \\
Top side assistants (9) & $5 \cdot 37(2 \cdot 39)$ & $2 \cdot 25(0 \cdot 55)$ & $66 \cdot 64(19 \cdot 54)$ \\
Lorry drivers (2) & $3 \cdot 82(0 \cdot 04)$ & $2 \cdot 26(0 \cdot 23)$ & $58 \cdot 32(7 \cdot 13)$ \\
Coke side assistants (13) & $3 \cdot 25(2 \cdot 59)$ & $1.56(0 \cdot 82)$ & $42 \cdot 75(29 \cdot 08)$ \\
Pusher machine operators (3) & $1 \cdot 64(0 \cdot 75)$ & $0 \cdot 64(0 \cdot 25)$ & $18 \cdot 82(6 \cdot 41)$ \\
P value (Kruskal-Wallis test) & $0 \cdot 015$ & $0 \cdot 0069$ & $0 \cdot 0054$ \\
P value (Jonckheere-Terpstra test) & $0 \cdot 00038$ & 0.00025 & $0 \cdot 00011$ \\
\hline
\end{tabular}

\section{AIR MONITORING}

Personal air PAHs were monitored for each coke oven worker during the whole shift with a Dupont P4000 pump, Dupont, USA, and a glass fibre filter ( $37 \mathrm{~mm}$ diameter) impregnated with silicone OV $225(70 \mathrm{mg})$. The workers were instructed to put masks on the filter system if they wore masks themselves. This was controlled by one of us who accompanied the workers for the whole shift.

\section{MEASUREMENT OF THE PAHS IN THE AIR}

SAMPLES

After filter extraction and analytical enrichment the following PAHs were measured: phenanthrene, anthracene, fluoranthene, pyrene, benzo(b)naphtho(2,1-d)thiophene, benzo(ghi)fluoroanthene, benzo(c)phenanthrene, cyclopenteno(cd)pyrene, benz(a)anthrancene, chrysene+ triphenylene, benzofluoranthenes $(b+j+k), \quad$ benzo(e)pyrene, benzo(a)pyrene, perylene, indeno(1,2,3-cd) pyrene, dibenz(a,h)anthracene, benzo(ghi)perylene, anthanthrene, coronene.

Details of the procedure have been described elsewhere. ${ }^{12}$ After defrosting to room temperature the urine samples were treated with glucuronidase/sulphatase for 16 hours at $37^{\circ} \mathrm{C}$ and $\mathrm{pH} 4 \cdot 67$. Phenols and dihydrodiols were separated by column chromatography on Extrelut with toluene as eluant as described by Grimmer et al. ${ }^{13}$

\section{STATISTICAL ANALYSIS}

Statistical analysis (Wilcoxon test, KruskalWallis test, Jonckheere-Terpstra test, Pearson correlation) was performed on a personal computer with the SAS program. All biomarker results were examined for correlations with smoking habits, alcohol intake, duration of working on coke ovens, exposure to PAHs, urinary metabolites, and lymphocyte subpopulations.

\section{Results}

It was possible to obtain air monitoring data for 27 workers (the personal air samplers did not work in two cases), and to analyse PAH metabolites in 24 hour urine samples from 26 workers (three did not collect urine over the night). Three matched pairs were excluded for biomarker results because the respective workers had worked only for two days after sickness absences of several weeks; we obtained results for the alkaline filter elution assay in 24 workers, counted sister chromatid exchanges in 25 workers and DNA adducts in 23 workers.

\section{PAH CONCENTRATION IN AIR SAMPLES}

Table 1 shows the concentrations of PAHs measured by personal air monitoring. There was a high correlation between the concentrations of phenanthrene, pyrene, and benzo(a)pyrene, and the concentration of total PAHs $(r=0.99,0.97$, and 0.97 , Pearson correlation).

Table 2 shows the concentrations of pyrene, benzo(a)pyrene, and total PAHs in relation to smoking habits and jobs at the coke oven. 
Table 3 Metabolites $(\mu g / 24 h)$ in the urine in 26 coke oven workers

\begin{tabular}{lcl}
\hline Metabolite & Mean $(S D)$ & Range \\
\hline Phenanthrene metabolites: & & \\
Phenols: & $0 \cdot 02(0 \cdot 05)$ & $0-0 \cdot 18$ \\
4-OH-phenanthrene & $0(0 \cdot 02)$ & $0-0 \cdot 10$ \\
9-OH-phenanthrene & $1 \cdot 54(1 \cdot 13)$ & $0 \cdot 29-4 \cdot 49$ \\
1-OH-phenanthrene & $1 \cdot 70(1 \cdot 29)$ & $0 \cdot 29-4 \cdot 64$ \\
4-OH-phenanthrene & $0 \cdot 82(0 \cdot 64)$ & $0 \cdot 11-2 \cdot 69$ \\
2-OH-phenanthrene & $4 \cdot 07(2 \cdot 96)$ & $0 \cdot 78-11 \cdot 81$ \\
Total phenols & 0 & \\
Dihydrodiols ${ }^{\text {4-OH-phenanthrene }}$ & $4 \cdot 40(4 \cdot 47)$ & 0 \\
9-OH-phenanthrene & $8 \cdot 53(8 \cdot 56)$ & $0 \cdot 40-16 \cdot 37$ \\
1-OH-phenanthrene & $1 \cdot 98(1 \cdot 52)$ & $0 \cdot 28-32 \cdot 26$ \\
3-OH-phenanthrene & $3 \cdot 73(3 \cdot 70)$ & $0 \cdot 37-14 \cdot 09$ \\
2-OH-phenanthrene & $18 \cdot 62(17 \cdot 87)$ & $1 \cdot 95-67 \cdot 42$ \\
Total dihydrodiols & $0 \cdot 02(0 \cdot 05)$ & $0-0 \cdot 18$ \\
Total phenols and dihydrodiols: & $4 \cdot 40(4 \cdot 48)$ & $0 \cdot 40-16 \cdot 37$ \\
4-OH-phenanthrene & $10 \cdot 06(9 \cdot 54)$ & $0 \cdot 97-34 \cdot 65$ \\
9-OH-phenanthrene & $3 \cdot 67(2 \cdot 61)$ & $0 \cdot 64-8 \cdot 88$ \\
1-OH-phenanthrene & $4 \cdot 54(4 \cdot 25)$ & $0 \cdot 47-15 \cdot 90$ \\
3-OH-phenanthrene & $22 \cdot 69(20 \cdot 43)$ & $2 \cdot 82-72 \cdot 92$ \\
2-OH-phenanthrene & $3 \cdot 56(2 \cdot 02)$ & $0 \cdot 66-8 \cdot 71$ \\
Total & $0 \cdot 66(0 \cdot 54)$ & $0 \cdot 07-2 \cdot 26$ \\
1-OH-pyrene metabolites: & $4 \cdot 22(2 \cdot 50)$ & $0 \cdot 73-10 \cdot 21$ \\
Phenol & & \\
Dihydrodiol & Total phenol and dihydrodiol &
\end{tabular}

*Measured as phenols after acidic dehydration with acetic acid and sulphuric acid.

Table 4 Excretion of metabolites (mean (SD) of the sums of phenanthrene and pyrene metabolites) by job in 26 workers

\begin{tabular}{lll}
\hline & \multicolumn{2}{l}{ Metabolite excretion $(\mu g / 24 h)$} \\
\cline { 2 - 3 } fob $(n)$ & $\begin{array}{l}\text { Phenanthrene } \\
\text { metabolites }\end{array}$ & $\begin{array}{l}\text { Pyrene } \\
\text { metabolites }\end{array}$ \\
\hline Top side assistants (8) & $35 \cdot 55(22 \cdot 77)$ & $5 \cdot 86(2 \cdot 81)$ \\
Lorry drivers (2) & $22.44(11 \cdot 52)$ & $6.03(1 \cdot 32)$ \\
Coke side assistants (13) & $16.43(19 \cdot 38)$ & $3.13(2 \cdot 11)$ \\
Pusher machine operators (3) & $15.66(9 \cdot 68)$ & $3.73(0.30)$ \\
P value (Kruskal-Wallis test) & 0.085 & 0.055 \\
P value (Jonckheere-Terpstra test) & 0.011 & 0.015 \\
\hline
\end{tabular}

Table 5 Significant correlations (Pearson) between the 24 h urinary metabolites (mean of the sums of phenanthrene and pyrene metabolites) and the respective air concentrations

\begin{tabular}{llll}
\hline Metabolite & $r$ & $P$ value & $n^{\star}$ \\
\hline Phenanthrene in air correlated with: & & & \\
9-OH-phenanthrene & 0.58 & 0.0033 & 24 \\
1-OH-phenanthrene & 0.54 & 0.0069 & 24 \\
3-OH-phenanthrene & 0.55 & 0.0052 & 24 \\
2-OH-phenanthrene & 0.51 & 0.010 & 24 \\
Total phenanthrene metabolites & 0.55 & 0.0049 & 24 \\
Pyrene in air correlated with: & & & \\
1-OH-pyrene & 0.44 & 0.033 & 24 \\
\hline
\end{tabular}

ऋThere were no air monitoring data in two of 26 workers with metabolite results.

Smokers seemed to be less exposed to PAHs in the workplace in our study. The concentrations of all PAHs were significantly increased on the top of the oven in comparison with the oven side (Wilcoxon test; increase for coronene not significant).

URINARY EXCRETION OF PAH METABOLITES

Table 3 shows the results of the measurement of PAH metabolites and table 4 shows the excretion of metabolites for different jobs.

There were only weak correlations (Pearson) between the metabolites in 24 hour urine samples and the respective air concentrations (table 5).

The influence of smoking on the excretion of the PAH metabolites has been calculated by estimating the content of one cigarette (mainstream smoke) to be $0.3 \mu \mathrm{g}$ phenanthrene and $0.2 \mu \mathrm{g}$ pyrene $^{14}$ and assuming complete ingestion of these amounts. The mean contribution of smoking to the total uptake was $3 \%$ (maximum $11 \%$ ) for pyrene and $7 \%$ (maximum $38 \%$ ) for phenanthrene. Taking smoking into account improved the correlations between the metabolites in urine and the uptake (from smoking and workplace air) of phenanthrene (Pearson, $\mathrm{n}=24, r=0.71, \mathrm{P}=0.0001$ ) and pyrene $(\mathrm{n}=24, r=0.53, \mathrm{P}=0.0082)$.

\section{BIOMARKER RESULTS}

In the alkaline filter elution assay no difference between the coke oven workers and the control group was found for DNA elution without proteinase $K$. There was a significant difference with proteinase $K$, thus indicating significantly more DNA single strand breaks in coke oven workers, but also DNA protein cross links (table 6). Coke oven workers who smoked had higher relative DNA elution rates (with proteinase $\mathrm{K}$ ) than controls who smoked; this indicated an increased DNA strand breakage frequency in coke oven workers who smoked. We did not find other differences with smoking.

The frequency of sister chromatid exchange was not significantly increased in the controls (table 6). In both groups smokers had more sister chromatid exchanges than non-smokers (coke oven workers $P=0.071$; controls $P=$ 0.018 ).

There were not significantly more DNA adducts in coke oven workers. Coke oven workers who smoked showed more DNA adducts than those who did not smoke (not significant); in the control group the result was opposite.

Table 7 shows the results of the biomarker measurement in coke oven workers with different jobs and PAH exposures. Only DNA adducts were increased (not significant) relative to the exposure to benzo(a)pyrene and total PAHs.

There were some weak correlations between the biomarkers and different factors of possible influence (smoking habits, alcohol intake, GSTT1 activity). There was a correlation between the number of sister chromatid exchanges and alcohol intake $(\mathrm{n}=25, r=$ $0.46, P=0.021$ ); a correlation with smoking was only found in controls $(\mathrm{n}=15, r=0.63$, $\mathrm{P}=0.012$ ). We detected a negative correlation between numbers of adducts and GSTT1 activity in erythrocytes of the coke oven workers ( $\mathrm{n}=20, r=-0.60, \mathrm{P}=0.0056$ ).

We measured lymphocyte subpopulations in the group of coke oven workers and controls. Significantly more NK cells (CD56) and proliferating cells (CD71) were found in coke oven workers than in controls (mean (SD) $19.33(2.66) v 8.13(2.13)$ and $30.6(2.59) v$ $19.91(2.31), P<0.01)$. Contrary to this the numbers of proliferating cells (CD71) in culture after stimulation with PHAs (during counting of sister chromatid exchanges) were higher in controls than in coke oven workers $(67.13(14.82)$ v 54.84 (3.85), $\mathrm{P}<0.05))$. From all the biomarker results only one positive correlation was found. This was between the number of sister chromatid exchanges in coke oven workers and CD8 positive lymphocytes ( $\mathrm{T}$ cells; $\mathrm{n}=23, \mathrm{r}=0.45, \mathrm{P}=0.031$ ).

We could not find significant correlations between smoking and the biomarker results in 
Table 6 Results of the alkaline filter elution, measurements of sister chromatid exchange, adducts in the lymphocytes of coke oven workers and standardised controls

\begin{tabular}{|c|c|c|c|c|}
\hline Variable & $n$ & $\begin{array}{l}\text { Coke oven } \\
\text { workers }\end{array}$ & Controls & $\begin{array}{l}\text { P value } \\
\text { (Wilcoxon } t \text { test) }\end{array}$ \\
\hline \multicolumn{5}{|l|}{ Alkaline filter elution: } \\
\hline \multicolumn{5}{|l|}{ Relative DNA elution rates } \\
\hline (Polycarbonate filter, - proteinase $\mathrm{K}$ ) & 24 & $0.98(0.39)$ & $0.95(0.62)$ & $0 \cdot 31$ \\
\hline Smokers & 14 & $1.05(0.41)$ & $0.88(0.68)$ & 0.063 \\
\hline Non-smokers & 10 & $0.88(0.37)$ & $1.05(0.54)$ & 0.43 \\
\hline (Polycarbonate filter, + proteinase $\mathrm{K}$ ) & 24 & $3.08(2.02)$ & $1.91(0.79)$ & 0.017 \\
\hline Smokers & 14 & $3 \cdot 29(2 \cdot 23)$ & $1.86(0.64)$ & 0.0082 \\
\hline Non-smokers & 10 & $2.79(1.75)$ & $1.98(0.99)$ & 0.39 \\
\hline \multicolumn{5}{|l|}{ Measurements of sister chromatid exchange: } \\
\hline Sister chromatid exchange: & 25 & $6 \cdot 16(0 \cdot 85)$ & $6.72(1.55)$ & $0 \cdot 15$ \\
\hline Smokers & 15 & $6.43(0.92)$ & $7.39(1.57)$ & 0.093 \\
\hline Non-smokers & 10 & $5 \cdot 74(0.54)$ & $5.92(1.00)$ & 0.91 \\
\hline \multicolumn{5}{|l|}{ DNA adduct determination: } \\
\hline DNA adducts $/ 10^{\circ}$ nuclei: & 23 & $7 \cdot 10(6 \cdot 59)$ & $4.45(5.83)$ & $0 \cdot 16$ \\
\hline Smokers & 14 & $7 \cdot 50(6 \cdot 46)$ & $3.86(1.60)$ & $0 \cdot 14$ \\
\hline Non-smokers & 9 & $6 \cdot 48(7 \cdot 14)$ & $5 \cdot 83(7 \cdot 68)$ & $0 \cdot 72$ \\
\hline
\end{tabular}

Table 7 Biomarker results (mean (SD)) for job and exposure to PAHs

\begin{tabular}{|c|c|c|c|c|}
\hline Exposure & $\begin{array}{l}\text { Relative DNA } \\
\text { elution rate } \\
\text { (polycarbonate filter } \\
\text { - proteinase K) } \\
\text { (n) }\end{array}$ & $\begin{array}{l}\text { Relative DNA } \\
\text { elution rate } \\
\text { (polycarbonate filter } \\
\text { + proteinase K) } \\
\text { (n) }\end{array}$ & $\begin{array}{l}\text { Sister } \\
\text { chromatid } \\
\text { exchange/cell } \\
(n)\end{array}$ & $\begin{array}{l}\text { DNA adducts } \\
110^{9} \text { nuclei } \\
\text { (n) }\end{array}$ \\
\hline \multicolumn{5}{|l|}{ Job: } \\
\hline Top side assistant & $0.92(0.41)(7)$ & $3.26(1.54)(7)$ & $5.98(0.98)(8)$ & $9 \cdot 81(6 \cdot 88)(7)$ \\
\hline Lorry driver & $1 \cdot 17(0.18)(2)$ & $2 \cdot 17(0.39)(2)$ & $5.28(0.79)(2)$ & $9 \cdot 15(8 \cdot 27)(2)$ \\
\hline Coke side assistant & $0.86(0.36)(12)$ & $2.87(2.58)(12)$ & $6.25(0.76)(12)$ & $4.67(6.08)(11)$ \\
\hline Pusher machine operator & $1.48(0.13)(3)$ & $4.08(0.67)(3)$ & $6.84(0.41)(3)$ & $8 \cdot 30(7 \cdot 27)(3)$ \\
\hline$P$ value (Kruskal-Wallis test) & 0.056 & $0 \cdot 25$ & $0 \cdot 17$ & $0 \cdot 30$ \\
\hline P value (Jonckheere-Terpstra test) & 0.49 & 0.87 & 0.93 & $0 \cdot 13$ \\
\hline \multicolumn{5}{|l|}{ Benzo(a)pyrene $\left(\mu \mathrm{g} / \mathrm{m}^{3}\right)$ : } \\
\hline$<1$ & $1 \cdot 17(0.36)(6)$ & $3.04(1.24)(6)$ & $6.47(0.79)(7)$ & $4 \cdot 77(6 \cdot 14)(6)$ \\
\hline $1-2$ & $0.91(0.33)(9)$ & $3.13(2.85)(9)$ & $6.08(0.63)(9)$ & $6.29(7.41)(8)$ \\
\hline$>2$ & $0.91(0.46)(9)$ & $3.05(1.62)(9)$ & $5.99(1.08)(9)$ & $9 \cdot 38(6 \cdot 10)(9)$ \\
\hline P value (Kruskal-Wallis test) & 0.40 & 0.78 & 0.56 & 0.27 \\
\hline P value (Jonckheere-Terpstra test) & 0.82 & 0.53 & 0.84 & 0.067 \\
\hline \multicolumn{5}{|l|}{ Total PAHs $\left(\mu \mathrm{g} / \mathrm{m}^{3}\right)$ : } \\
\hline$<30$ & $1.03(0.41)(8)$ & $2.63(1.32)(8)$ & $6.48(0.72)(9)$ & $5 \cdot 14(5 \cdot 50)(8)$ \\
\hline $30-60$ & $0.91(0.38)(10)$ & $3.54(2.66)(10)$ & $5.93(0.80)(9)$ & $7.96(8.75)(9)$ \\
\hline$>60$ & $1.02(0.44)(6)$ & $3.07(1.72)(6)$ & $6.02(1.03)(7)$ & $8 \cdot 43(4 \cdot 11)(6)$ \\
\hline P value (Kruskal-Wallis test) & 0.94 & 0.86 & 0.35 & 0.48 \\
\hline$P$ value (Jonckheere-Terpstra test) & 0.50 & 0.32 & 0.85 & $0 \cdot 14$ \\
\hline
\end{tabular}

the subgroups that smoked. There were no correlations between the biomarker results and exposure to pyrene and phenanthrene when smoking was taken into account.

There were no correlations between the different biomarkers.

\section{Discussion}

EXPOSURE TO PAHS

We investigated a group of coke oven workers who were exposed to benzo(a)pyrene concentrations below the German technical exposure limit $\left(5 \mu \mathrm{g} / \mathrm{m}^{3}\right.$ for coke ovens). ${ }^{1}$ Personal air monitoring showed a mean benzo(a)pyrene concentration of $1.74 \mu \mathrm{g} / \mathrm{m}^{3}$ with a maximum of $3.55 \mu \mathrm{g} / \mathrm{m}^{3}$ (table 1 ). We found a good correlation between the phenanthrene, pyrene, and benzo(a)pyrene concentrations in the air and the total PAHs measured. Therefore, all of the three compounds seem to be good indicators of exposure to total PAHs and could be used as indicators in other coke ovens to compare the exposure on different coke ovens, at least if the emission profiles of the coke ovens were known.

Workers on the top of the oven had the highest exposures to PAHs (table 2). The exposure decreased from top side assistants to lorry drivers, workers at the side of the oven and pusher machine operators. Similar results have been reported by other authors. ${ }^{15} 16$ The real intake of PAHs may be much higher than indicated by air monitoring. VanRooij et al ${ }^{17}$ estimated a dermal uptake of benzo(a)pyrene of $51 \%$ and of pyrene of $75 \%$ in coke oven workers. The intake of benzo(a)pyrene from smoking seems to be low relative to the intake from workplace air: The mean intake of benzo(a)pyrene from smoking $(0.04 \mu \mathrm{g} / \mathrm{ciga}$ rette, 20 cigarettes/day) may reach $0.8 \mu \mathrm{g} /$ day, whereas the uptake at the workplace may be about $17 \mu \mathrm{g} /$ day $\left(1.7 \mu \mathrm{g} / \mathrm{m}^{3}, 10 \mathrm{~m}^{3}\right.$ every shift).

\section{BIOLOGICAL MONITORING}

We measured different metabolites of phenanthrene and pyrene in 24 hour urine samples (table 3), and found differences of a factor of 20-30 between workers whereas the phenanthrene and pyrene air concentrations differed only by a factor of 15 at the most. This may indicate metabolic differences between people-for example, enzyme polymorphisms. Santella et al ${ }^{18}$ found differences in excretion of hydroxypyrene of a factor of 20 in people with comparable exposure to PAHs. As in a previous investigation ${ }^{13}$ phenanthrene was mainly excreted as dihydrodiol conjugate and pyrene as phenol conjugate.

The sum of both metabolites was greatest in the urine of the workers on the top of the oven (table 4).

Different authors have reported a (significant or at least a semiquantitative) correlation between hydroxypyrene in urine and concen- 
trations of pyrene or total PAHs in the workplace air for coke oven and coal liquification workers. ${ }^{19-21}$ In our investigation the correlation between concentrations in air and urinary metabolites was better for phenanthrene than for pyrene (table 5). Both metabolites correlated only weakly with the concentration of total PAHs. The correlation between the concentrations of phenanthrene and pyrene and total PAHs in urine was better when smoking was taken into account. So in our investigation the measurement of phenanthrene metabolites seems to be the better variable for biological monitoring. Smoking seems to have important influences on the value of PAH metabolites in urine; as also indicated by other authors. ${ }^{22-24}$ Elovaara et $a l^{25}$ concluded that the dermal uptake of pyrene may be very high because in their study on creosote workers an up to 50fold higher daily urinary excretion of hydroxypyrene was found compared with that calculated from the uptake from air.

\section{BIOMARKERS}

Alkaline filter elution showed a significantly increased frequency of DNA single strand breakages in the coke oven workers and additional DNA protein cross links (table 6). There were no significant influences of the workplace, exposure to PAHs, or excretion of metabolites (table 7).

Fuchs et $a l^{26}$ reported that DNA strand breaks in roofers were significantly increased during the working week. It has also been shown in vitro and in vivo that smoking and PAHs may cause DNA single strand breaks $^{27-32}$; PAHs may do this by oxidative damage. ${ }^{33}$ It has been shown that the amount of oxidative damage caused by benzo(a)pyrene is 20 times greater than the damage by adducts. ${ }^{34}{ }^{35} \mathrm{We}$ also found an increased rate of single strand breaks in patients with oral cancer in whom smoking may have played an important part in carcinogenesis. ${ }^{36}$

We detected increased numbers of DNA adducts in lymphocytes of coke oven workers who smoked, although this was not significant.

DNA adducts did not correlate with exposure to PAHs or metabolite excretion, but increased with semiquantitative increases in exposure to PAHs and benzo(a)pyrene, although again this was not significant (table 7). Most studies on coke oven workers did not find correlations with exposure. Only a few studies have reported correlations between DNA adducts and exposure to PAHs. ${ }^{2137-40}$ Van Schooten et al ${ }^{21}$ described a good correlation between DNA adducts in workers who smoked and were exposed to PAHs and the excretion of hydroxypyrene in urine.

In a former investigation on a coke oven we found no differences between smokers and non-smokers, in either coke oven workers or controls. ${ }^{10}$ The number of adducts was significantly increased in exposed workers, regardless whether smoking was taken into account or not. However, the exposure to benzo(a)pyrene was about twice that in our present study.

In the coke oven workers there was a significantly negative correlation between adducts and GSTT1 activity in erythrocytes. Santella et $a^{41}$ detected no correlation between the GSTM1 genotype patients with psoriasis treated with coal tar and PAH adducts in white blood cells. Whether GSTT1 metabolises PAHs is not known. ${ }^{42}$ Our results may indicate at least an induction of phase II enzymes leading to increased detoxification of DNA reactive metabolites of PAHs.

The frequency of sister chromatid exchange was reduced, but not significantly in coke oven workers and was also lower than that in a larger control group at our institute $(n=78$, mean number of sister chromatid exchanges $6 \cdot 27$, not significant). Smokers had more sister chromatid exchanges in both coke oven workers and the control group, but again this was not significant for the coke oven workers. Thus measurement of sister chromatid exchange does not seem to be a good biomarker in coke oven workers; not surprising in view of the conflicting published results of numbers of sister chromatid exchanges in coke oven workers. ${ }^{163743-45} \mathrm{We}$ also found less sister chromatid exchanges in workers exposed to chromium/nickel and ethylene oxide than in controls. ${ }^{546}$

It is known that there are more sister chromatid exchanges in CD8 positive lymphocytes than in CD4 and CD19 positive lymphocytes. Correlations between sister chromatid exchanges and the absolute number of $T$ lymphocytes in blood have been described. ${ }^{47}$ The correlation between sister chromatid exchanges and CD8 positive lymphocytes in the blood of coke oven workers might be a consequence of an increased proliferation of CD8 positive lymphocytes, ${ }^{48}$ in cultures. This reduced the time to damage chromosomes. In the coke oven workers we found a weak correlation between the number of sister chromatid exchanges and alcohol intake-a similar correlation was found in patients with oral cancer in whom alcohol misuse and smoking were the main causes of carcinogenesis. ${ }^{49}$

In the lymphocyte subpopulations we found significantly increased numbers of NK cells (CD56) and proliferating cells (CD71). This may indicate immunotoxic influences. The reduced number of proliferating cells in culture after stimulation with PHAs might be interpreted as indicating a cellular immune defect due to exposure. Tanigawa et $a \Gamma^{0}$ described reduced numbers of CD4 and CD8 positive lymphocytes in the blood of retired chromate workers. Increased numbers of Bcells were found in smokers ${ }^{51}$ and reduced numbers in traffic policemen ${ }^{52}$ and workers exposed to arylamines. ${ }^{53}$ Possible immunotoxic influences of exposure to PAHs need further investigation.

In summary, we investigated a group of coke oven workers exposed to PAHs below the German limit for benzo(a)pyrene in air ( $5 \mu \mathrm{g} / \mathrm{m}^{3}$ for coke ovens). Concentrations of phenanthrene and pyrene as well as benzo(a)pyrene seem to represent the concentration of total PAHs in air very well; they might be used for comparisons of different workplaces if the emission compositions are 
known. Phenanthrene metabolites in urine proved to be better biological monitoring variables than 1-hydroxypyrene, if only the intake of PAHs by inhalation is taken into account. The alkaline filter elution assay showed significantly more DNA strand breaks in lymphocytes of coke oven workers than in controls; the DNA adduct rate was not significantly increased in workers, but correlated with exposure to PAHs in a semiquantitative manner. The measurement of sister chromatid exchanges was not a good variable for biomonitoring of coke oven workers.

Finally, we found indications for immunotoxic influences, which should be studied in further investigations. Detection of genotoxic effects by alkaline filter elution proved to be the most sensitive variable (alkaline filter elution $<$ DNA adducts by postlabelling $>$ sister chromatid exchange). Only DNA adducts in the nuclease P1 modified form of the postlabelling assay showed a relative specificity for $\mathrm{PAH}$ adducts. We conclude that in biomarker studies variables with high sensitivity for genotoxic damage and specificity for damage caused by known compounds should always be combined.

We are grateful to Elisabeth Jeske, Eva Nowotzki, and Heike Engelberg-Wiegand for their valuable technical assistance. The study was supported by grants from the Bundesministerium für Forschung und Technologie, Bonn, Germany (01HK740A/7, 01 HK730A/9).

1 DFG. List of $M A K$ and $B A T$ values 1996. Weinheim: $\mathrm{VCH}$ 1996.

2 Doerjer G, Buchholz U, Kreuzer K. Oesch F. Biomonitoring of DNA damage by alkaline filter elution. Int Arch Occup Environ Health 1988;60:169-74.

3 Kohn KW, Ewig RAG, Erickson LC, Zwelling LA. Measurement of strand breaks and cross-links by alkaline elution. In: Friedberg EC, Hanawalt PD, eds. DNA repair: a laboratory manual of research procedures. Basel: repair: a laboratory manua

4 Stout DL, Becker FF. Fluorometric quantitation of singlestranded DNA: a method applicable to the technique of alkaline elution. Anal Biochem 1982;127:302-7.

5 Popp W, Vahrenholz C, Schmieding W, Krewet E Norpoth $K$. Investigations of the frequency of DNA strand breakage and cross-linking and of sister chromatid exchange in lymphocytes of electric welders exposed to chromium- and nickel-containing fumes. Int Arch Occup Environ Health 1991;63:115-20.

6 Popp W, Vahrenholz C, Yaman S, Müller C, Müller G, Schmieding $W$, et al. Investigations of the frequency of DNA strand breakage and cross-linking and of sister chromatid exchange frequency in the lymphocytes of chromatid exchange frequency in the lymphocytes of female workers exposed to

7 Perry P, Wolff S. New Giemsa method for the differential staining of sister chromatids. Nature 1974;251:156-8.

8 Reddy MV, Randerath K. ${ }^{32} \mathrm{P}$-analysis of DNA adducts in somatic and reproductive tissues of rats treated with the anticancer antibiotic mitomycin C. Mutat Res 1987;179. 75-88.

9 Reddy MS, Randerath K. Nuclease P1-mediated enhancement of sensitivity of ${ }^{32} \mathrm{P}$-postlabelling test for structurally diverse DNA adducts. Carcinogenesis 1986;7:1543-51.

10 Schell C, Popp W, Kraus R, Vahrenholz C, Norpoth K ${ }^{32} \mathrm{P}$-postlabeling analysis of DNA adducts in differen populations. Toxicol Lett 1995;77:299-307.

11 Peter H, Deutschmann S, Reichel C, Hallier E, Metabolism of methyl chloride by human erythrocytes. Arch Toxicol 1989;63:351-5.

12 Grimmer, G, Naujack K-W, Schneider D. Profile analysis of polycyclic aromatic hydrocarbons by glass capillary gas of polycyclic aromatic hydrocarbons by glass capillary gas
chromatography in atmospheric suspended particulate matter in the nanogram range collecting $10 \mathrm{~m}^{3}$ of air. matter in the nanogram range collecting $10 \mathrm{~m}^{3}$ of air.
Fresenius Zeitschrift für analytische Chemie. 1982;311: 189-99.

13 Grimmer G, Dettbarn G, Jacob J. Biomonitoring of polycyclic aromatic hydrocarbons in highly exposed coke plant workers by measurement of urinary phenanthrene and pyrene metabolites (phenols and dihydro

14 International Agency for Research on Cancer. LARC monographs on the evaluation of the carcinogenic risk of chemicals to humans. Tobacco smoking. Vol 38. Lyon: IARC, 1985.

5 Jongeneelen FJ. Biological exposure limit for occupational exposure to coal tar pitch volatiles at coke ovens. Int Arch Occup Environ Health 1992;63:511-6.

16 van Hummelen P, Gennart JP, Buchet JP, Lauwerys R, Kirsch-Volders $M$. Biological markers in PAH exposed workers and controls. Mutat Res 1993;300:231-9.

17 VanRooij JGM, Bodelier-Bade MM, Jongeneelen FJ. Estimation of individual dermal and respiratory uptake of polycyclic aromatic hydrocarbons in 12 coke oven workers. Br F Ind Med 1993;50:623-32.

18 Santella RM, Hemminki K, Tang D-L, Paik M, Ottman R, Young TL, et al. Polycyclic aromatic hydrocarbon-DNA adducts in white blood cells and urinary 1-hydroxypyrene in foundry workers. Cancer Epidemiol Biomark Prev 1993; in found $2: 59-62$.

19 Cenni A, Sciarra G, Sartorelli P, Pappalardo F. Environmental and biological monitoring of polycyclic aromatic hydrocarbons (PAHs) in coke plants and other workplaces. Med Lav 1993;84:379-86.

20 Quinlan R, Kowalczyk G, Gardiner K, Hale K, Walton S, Calvert I. Urinary 1-hydroxypyrene: a biomarker for polycyclic aromatic hydrocarbon exposure in coal liquefaction workers. Occup Med 1995;45:63-8.

21 van Schooten FJ, Jongeneelen FJ, Hillebrand MJX, van Leeuwen FE, de Looff AJA, Dijkmans APG, et al. Polycyclic aromatic hydrocarbon-DNA adducts in white blood cell DNA and 1-hydroxypyrene in the urine from aluminium workers: relation with job category and syneraluminium workers: relation with job category and synergistic effect of

22 Burgaz S, Borm PJA, Jongeneelen FJ. Evaluation of urinary excretion of 1-hydroxypyrene and thioethers in workers exposed to bitumen fumes. Int Arch Occup Environ Health 1992;63:397-401.

23 Sherson D, Sigsgaard T, Overgaard E, Loft S, Poulsen HE, Jongeneelen FJ. Interaction of smoking, uptake of polycyclic aromatic hydrocarbons, and cytochrome P450IA1 activity among foundry workers. $\mathrm{Br} F$ Ind Med 1992;49: 197-202.

24 Sherson D, Omland O, Hansen AM, Sigsgaard T, Autrup $\mathrm{H}$, Overgaard E. Biomarkers in PAH-exposed iron foundry workers. The Amold O Beckman IFCC European Conference on Environmental Toxicology. Biomarkers of chemical expoon Environmental Toxicology. Biomarkers of chem
sure. Munich: Arnold O Beckman IFCC, 1993.

25 Elovaara E, Heikkilä P, Pyy L, Mutanen P, Riihimäki V. Significance of dermal and respiratory uptake in creosote workers: exposure to polycyclic aromatic hydrocarbons and urinary excretion of 1-hydroxypyrene. Occup Environ Health 1995;52:196-203.

26 Fuchs J, Hengstler JG, Boettler G, Oesch F. Primary DNA damage in peripheral mononuclear blood cells of workers exposed to bitumen-based products. Int Arch Occup Environ Health 1996;68:141-6.

27 Holz O, Meißner R, Einhaus M, Koops F, Warncke $K$, Scherer G, et al. Detection of DNA single-strand breaks in lymphocytes of smokers. Int Arch Occup Environ Health 1993;65:83-8.

28 International Agency for Research on Cancer. LARC monographs on the evaluation of the carcinogenic risk of chemicals to graphs on the evaluation of the carcinogenic risk of chemicals to
humans. Polymuclear aromatic compounds, part 3, industrial exposures in aluminium production, coal gasification, coke production, and iron and steel founding. Vol 34. Lyon: IARC, 1984

29 Nakayama T, Kaneko M, Kodama M, Nagata C. Cigarette smoke induces DNA single-strand breaks in human cells. Nature 1985;314:462-4

30 Salagovic J, Kalina I, Dubayova K. Induction of single strand DNA breaks in workers professionally exposed to polycyclic aromatic hydrocarbons. Neoplasma 1995;42: 115-8.

31 Stone KK, Bermúdez E, Pryor WA. Aqueous extracts of cigarette tar containing the tar free radical cause DNA nicks in mammalian cells. Environ Health Perspect nicks in mammalian cells.

32 Einhaus $M$, Holz O, Meißner $R$ Krause $T$, Warncke $K$, Held I, et al. Determination of DNA single-strand breaks in lymphocytes of smokers and non-smokers exposed to in lymphocytes of smokers and non-smokers exposed to environmental tobacco smoke using

33 Leadon SA, Sumerel J, Minton TA, Tischler A. Coal tar residues produce both DNA adducts and oxidative DNA damage in human mammary epithelial cells. Carcinogenesis 1995;16:3021-6.

34 Frenkel K. Carcinogen-mediated oxidant formation and oxidative DNA damage. Pharmacol Ther 1992;53: $127-66$.

35 Leadon SA, Stampfer MR, Bartley J. Production of oxidative DNA damage during the metabolic activation of benzo(a)pyrene in human mammary epithelial cells correlates with cell killing. Proc Natl Acad Sci USA 1988;85: 4365-8.

36 Popp W, Schell C, Kraus R, Vahrenholz C, Wolf R, Radtke $\mathrm{J}$, et al. DNA strand breakage and DNA adducts in lymphocytes of oral cancer patients. Carcinogenesis 1993;14:2251-6.

37 Buchet JP, Ferreira M, Burrion JB, Leroy $T$, KirschVolders $M$, van Hummelen $P$, et al. Tumor markers in Volders $M$, van Hummelen $P$, et al. Tumor markers in serum, polyamines and modified nucleosides in urine, and cytogenetic aberrations in lymphocytes of workers Med 1995;27:523-43.

38 Assennato G, Ferri GM, Foa V, Strickland P, Poirir M, Pozzoli L, Cottica D. Correlation between PAH airborne 
concentration and PAH-DNA adducts levels in cokeoven workers. Int Arch Occup Environ Health 1993; 65:S143-5.

39 Binkova B, Lenicek J, Miskova I, Milcova A, Plna K, Sram $R$, Lewtas J. DNA adducts and personal exposure monitoring data of a selected population group from a high polluted area in the Czech republic. Zbl Hyg 1994;195: 215-6.

40 Herbert R, Marcus M, Wolff MS, Perera FP, Andrews L, Godbold $\mathrm{JH}$, et al. Detection of adducts of deoxyribonucleic acid in white blood cells of roofers by ${ }^{32} \mathrm{P}-$ postlabeling. Scand f Work Environ Health 1990;16:135-43.

41 Santella RM, Perera FP, Young TL, Zhang Y-J, Chiamprasert S, Tang D, et al. Polycyclic aromatic hydrocarbon-DNA and protein adducts in coal tar treated patients and controls and their relationship to glutathione S-transferase genotype. Mutat Res 1995;334: 117-24.

42 Nelson HH, Wiencke JK, Christiani DC, Cheng TJ, Zuo $\mathrm{Z}-\mathrm{F}$, Schwartz BS, et al. Ethnic differences in the preva-
lence of the homozygous deleted genotype of glutathione S-transferase theta. Carcinogenesis 1995;16:1243-5.

43 Bender MA, Leonard RC, White O, Costantino JP, Redmond CK. Chromosomal aberrations and sisterchromatid exchanges in lymphocytes from coke-oven chromatid exchanges in lymphocy

44 Miner JK, Rom WN, Livingston GK, Lyon JL. Lymphocytes sister chromatid exchange (SCE) frequencies in cytes sister chromatid exchange (SCE) frequen
coke oven workers. $\mathcal{F}$ Occup Med 1983;25:30-3.

45 Reuterwall C, Aringer L, Elinder C-G, Rannug A, Levin J$\mathrm{O}$, Juringe L, Önfelt A. Assessment of genotoxic exposure in Swedish coke-oven work by different methods of biological monitoring. Scand $f$ Work Environ Health 1991;17:123-32

46 Popp W, Vahrenholz C, Przygoda H, Brauksiepe A, Goch S, Müller G, et al. DNA-protein cross-links and sister chro- matid exchange frequencies in lymphocytes and hydroxyethylmercapturic acid in urine of ethylene oxideexposed hospital workers. Int Arch Occup Environ Health 1994;66:325-32.

47 Mertens R, Rubbert F, Büssing A. Childhood acute lymphoblastic leukemia (ALL): sister chromatid exchange (SCE) frequency and lymphocyte subpopulations during therapy. Leukemia 1995;9:501-5.

48 Kraus R, Kling R, Vahrenholz C, Popp W, Schell C, Norpoth K. Einfluß von Lebensstilfaktoren und methodischen Ansätzen auf Schwesterchromatidaustauschraten von Lymphozyten. In: Triebig G, Stelzer O, eds. Bericht über die 33. fahrestagung der Deutschen Gesellschaft für über die 33. Fahrestagung der Deutschen Gesellschaft für
Arbeitsmedizin und Umweltmedizin e.V. Stuttgart: Gentner, 1993:473-7.

49 Popp W, Wolf R, Vahrenholz C, Radtke J, Schell C, Kraus $\mathbf{R}$, et al. Sister chromatid exchange frequencies in lymphocytes of oral cancer patients seem to be influenced by drinking habits. Carcinogenesis 1994;15:1603-7.

50 Tanigawa T, Araki S, Araki T, Minato N, Yokoyama K. Decreases of CD4- and CD8-positive $\mathrm{T}$ lymphocytes in retired chromate workers. Am 7 Ind Med 1995;27: 877-82.

51 Mili F, Flanders WD, Boring JR, Annest JL, Destefano F. The associations of race, cigarette smoking, and smoking cessation to measures of the immune system in middle-

52 Cervone M, Boscolo P, Sabbioni E, Pavone D, Di Giacomo F, Jasonna G, Giuliano G. Lymphocyte subpopulations of traffic policemen in a town of central Italy (preliminary study). Int $\mathcal{F}$ Immunopathol Pharmacol 1995; 8:15-22.

53 Sung HL, Araki S, Tanigawa T, Sakurai S. Selective decrease of the suppressor-inducer $\left(\mathrm{CD}^{+} \mathrm{CD}^{+} 5 \mathrm{RA}^{+}\right) \mathrm{T}$ lymphocytes in workers exposed to benzidine and betanaphthylamine. Arch Environ Health 1995;50:196-9.

\section{Correspondence and editorials}

Occupational and Environmental Medicine welcomes correspondence relating to any of the material appearing in the journal. Results from preliminary or small scale studies may also be published in the correspondence column if this seems appropriate. Letters should be not more than 500 words in length and contain a minimum of references. Tables and figures should be kept to an absolute minimum. Letters are accepted on the understanding that they may be subject to editorial revision and shortening.

The journal also publishes editorials which are normally specially commissioned. The Editor welcomes suggestions regarding suitable topics; those wishing to submit an editorial, however, should do so only after discussion with the Editor. 